\title{
The Effective Role of Soil Indigenous Fungi on 2.4-D Herbicide Degradation
}

\author{
Abdulridha Taha Sarhan \\ Private Hilla University College, Babylon \\ Ministry of Higher Education and Scientific Research, Iraq \\ Sharie almahkamat, Al Hillah, Iraq. 51001 \\ E-mail: almakhadree52@hilla-unc.edu.iq
}

\begin{abstract}
The normal field soil environment safeguarded, via indigenous microbes in a native manner, with the aim of turning herbicide waste into productive bio-resources, through fungi activities. This study aims to determine the effective role of soil indigenous fungi on 2.4-D herbicide degradation. The research was conducted over a period of six weeks, on Iraqi cereal field. A total of eight fungi species, belonging to six genera, (Aspergillus candidus L. ATCC 1002, A. niger T. ATCC 16888, Curvularia lunata W. B1933, Penicillium sp. L. 1809, Rhizopus stolonifer L. B9770, Stachybotrys atra C. 1837, Trichoderma harzianum R. IOC 3844, and T. lignorum T. Hartz 1872), were isolated from the soil. During the exposure periods, fungal populations were differently affected, upon treatments with herbicide. The applied herbicide treatments showed different effects on growth and development of the isolated fungi. The results showed that, five of the eight fungi species (C. lunata B1933, Penicillium sp. 1809, R. stolonifer B9770, T. harzianum IOC 3844, and $T$. lignorum Hartz 1872) were greatly enhanced by the treatment process. However, two fungi ( $S$. atra 1837, and A. candidus ATCC 1002) were affected negatively by the herbicide, while one (A. niger ATCC 16888) remained unaffected. Once extracted from the soil of wheat fields in Iraq, the fungus $S$. atra 1837 , was first isolated. The highest inhibitory effect was caused by $2.4-\mathrm{D}$ herbicide, on the toxigenic fungus $S$. atra, causing its disappearance from the field at the last week of application. The laboratory experiments showed similar herbicide effects on the isolated fungi at low and moderate levels, while those at the high level $(800 \mu \mathrm{g} / \mathrm{ml})$ were toxic. These results showed that the herbicide 2.4-D treatments have substantial effects on microbial population in the field. When applied at recommended field rate, the herbicide causes transient impacts on fungal population growth and biodiversity, with the majority of the organism becoming responsible for 2.4-D mineralization in the soil. Therefore, the use of 2.4-D herbicide does not only control weed population, but it also affects microbial activities, especially indigenous fungi in the soil.
\end{abstract}

Keywords: fungal population; herbicide degradation; indigenous microorganisms; soil fungi; 2.4-D residue

Article History: Received 10 September 2020; Received in revised form 15 October 2020; Accepted 11 November 2020; Available online 30 December 2020

How to Cite This Article: Sarhan AT. 2020. The effective role of soil indigenous fungi on 2.4-D herbicide degradation. Biogenesis: Jurnal Ilmiah Biologi. vol 8(2): 195-202. doi: https://doi.org/10.24252/bio.v8i2.16802.

\section{INTRODUCTION}

Presently, environmental protection has the foremost importance in humans' life. One of the causes of adverse effects on soil environment is herbicide (2.4-D), a weed killer for cereal crops, which is capable of causing damages when used intensively (Nykiel-Szymańska et al., 2018). In the past, the trend to search and utilize soil native fungi is a preventive method that do not alter natural ecosystems (Diez, 2010). Biological environmental remediation is an expressive and effective method for contaminant removal from soil environment through fungal metabolism (Urík et al., 2016; Goswami et al., 2018). Therefore, the roles of fungi in regulating the degradation of 2.4-D have been widely studied (Ferreira-Guedes et al., 2012; Treu \& Falandysz, 2017; Bernat et al. 2018). It was observed that 2.4-D biodegradation is specifically carried out by fungi, placing them in consideration as good agent for bioconversion (Kumar et al., 2016; Serbent et al., 2019). Also, it was observed that, metabolic activity of microorganisms, contributes to the remediation of soil bound residues (Botero et al., 2017). However, an ideal herbicide should have quick ability to be degraded into non-toxic substances that ultimately exert less toxic effects on soil microbes (Xia et al., 2017). Recently, it was discussed that 2.4-D is among the most widely distributed soil pollutants in the environment, and showed antagonistic interactions against microorganisms ( $\mathrm{Ju}$ et al., 2019), with the knowledge that microbial endophytes (bacteria and fungi), already contributes more to herbicide detoxification (Tétard-Jones \& Edwards, 2016; Nikolaivits et al., 2019). 
Furthermore, microbial communities exert important roles in maintaining soil health and productivity of crops (Fernando \& Li, 2012). However, it was observed by Zain et al. (2013) that herbicides affecting soil microorganisms are responsible for numerous biological processes, essential for crop production. The herbicide 2.4-D is susceptible to soil microbial degradation, while some do not (Zhang et al., 2010). Also, the studies of Fang et al. (2012) and Banks et al. (2014) showed that 2.4-D herbicide has significant substantial effects on microbial population. The reaction of soil microbial activities to herbicide treatment and high microorganism community stress adaptation, is caused by the increase in concentration of herbicides, over the weeks of treatment (Adomako \& Akyeampong, 2016). Therefore, the results of 2.4-D herbicide on in vitro growth of soil borne fungi, exhibited an inhibitory effect (Ceballos et al., 2011). This study aims to isolate indigenous fungi from Iraqi cereal soil, which had been contaminated with 2.4-D herbicide, and to analyze their efficiency for degradation, as well as the effect of the chemical on the fungal population

\section{MATERIALS AND METHODS}

Herbicide treatments. The herbicide 2.4-

D (2.4-dichlorophenoxyacetic acid), was obtained from a local agricultural dealer store in Iraq. The herbicide treatments were carried out for a period of six weeks at company recommended field rate of $1350 \mathrm{~g}$ ai/ha, by using a $16 \mathrm{~L}$ sprayer. The exposure periods were, one, two, three, four, five and six weeks after treatment (WAT).

Soil samples. The samples were obtained from the upper field $(0-15 \mathrm{~cm})$ to the middle of Iraq. Three soil specimens, $1 \mathrm{~kg}$ each, were collected randomly from different places within the field, and mixed thoroughly to form a composite sample. The soil samples were sieved through a $2.0 \mathrm{~mm}$ mesh size, to remove large particles and plant debris, while being stored at $4^{\circ} \mathrm{C}$ for 3 days, before use (Ross, 1992; van de Voorde et al., 2012). The $\mathrm{pH}$ value, physical, and chemical properties of sampled soils were determined (Table 1).
Table 1. Physical and chemical characteristics of the soil sampled from wheat plantation.

\begin{tabular}{ll}
\hline \multicolumn{1}{c}{ Characteristic } & \multicolumn{1}{c}{ Value } \\
\hline Soil texture/Silt clay & Silt $54 \%$, Clay $40 \%$, \\
& Sand $6 \%$ \\
Soil pH & $5.1 \pm 0.2$ \\
Soil moisture & $34.18 \%$ \\
Organic matter (OM) & $1.85 \%$ \\
Electronic conductivity & (EC) $2.3 \mu \mathrm{sem} . / \mathrm{cm}$ \\
Cat-ion exchange & $34 \mathrm{~m} \mathrm{eq./100} \mathrm{gm}$ \\
capacity(CIEC) & \\
\hline
\end{tabular}

Herbicide residue in soil. From the upper layer (0-15 depth), soil samples at the experimental fields, obtained at different times (weeks) after treatment with 2.4-D herbicide, were analyzed according to the method of Botero et al. (2017). The microbial contribution to the formation of bound residues in soils, was studied by characterizing the metabolic activity of soil fungi, during incubation in synthetic liquid media and soil.

Isolation of fungi. Potato dextrose agar with antibiotics (PDA+a), was used for enumeration and isolation of fungi. After autoclaving and cooling PDA to $45^{\circ} \mathrm{C}$, the medium was supplemented with chloramphenicol $(100 \mathrm{mg} / \mathrm{L})$, dissolved in $5 \mathrm{ml}$ of sterile distilled water. Fungi were isolated, by plating $0.5 \mathrm{ml}$ of $1 \times 10^{-3}$ dilution of the soil particles on PDA plates. The plates were incubated in the dark at $25^{\circ} \mathrm{C}$, and screened for two weeks. Fungal hyphae growing from particles, were transferred to PDA plates. Fastgrowing fungi were cut out from the plates after isolation, to prevent them from growing over those that emerged later, and were purified. Colonies of fungi on PDA, were characterized morphologically, based on colony morphology, conidial and hyphal structures (Diana et al., 2019).

Fungal population and herbicide residues in the soil /field experiments. These experiments were conducted, according to the procedure of Zain et al. (2013). Soil samples were obtained at 0-6 WAT to assess the effect on the fungal population, herbicidal in the soil. Four sub-samples were obtained randomly from each samples, using sterile cork borer (10 $\mathrm{mm}$ diameter), then mixed together. Serial dilutions were made from each sample aseptically up to $10^{-4}$ to complete the process. 
Ten drops of $1 \times 10^{-3}$ dilution were pipetted out by drop plate method onto a growth media (PDA). The inoculated media plates were then incubated in darkness at $25^{\circ} \mathrm{C}$. Fungal population in the PDA plates were then enumerated by their colony forming unit (CFU). After seven days, the CFUs were determined, by counting the visible colonies.

Fungal population and herbicide residues in the soil/lab experiments. This study was carried out with two independent experiments, first is the radial growth in solid media (PDA), and second is the mycelial mat in liquid media (PDB). These experiments were carried out in optimal nutritional conditions, for mycelia growth of fungi. Furthermore, the solid and liquid media were amended with buffer solution, to avoid $\mathrm{pH}$ modification, by herbicide solutions. In this study, three different concentrations (rates) of the herbicide treatment, 200, 400 and $800 \mu \mathrm{g} / \mathrm{ml}$, were applied, and represented half, one and two times $(x)$ their recommended field rates (1350 $\mathrm{g}$ a.i./ha). These 2.4-D concentrations were mixed with autoclaved PDA medium or PDB liquid media, before solidity (at around $45^{\circ} \mathrm{C}$ ), after which they are placed in Petri plates, inoculated with test fungi, incubated at $45^{\circ} \mathrm{C}$ for one week, then examined for mycelial growth and sporulation. Five-mm diameter agar plugs, using a sterile cork borer, were obtained from the edge of the actively growing fungal colonies (one-week-old culture), placed in the center of the herbicide-amended dishes $(90 \mathrm{~mm}$ diameter), and incubated at $25^{\circ} \mathrm{C}$ in complete darkness for six days.

The effect of herbicides on the fungal species, were measured by the radial growth of fungal colonies in both control, and treated PDA plates, using millimeter ruler after 6 days incubation period. However, spore suspension of the test fungi, was used for the inoculation of PDB flasks. Liquid culture studies were conducted in $250 \mathrm{ml}$ erlenmeyer flasks, containing $100 \mathrm{ml}$ of PDB, supplemented with herbicide. One milliliter of the spore suspension was introduced under aseptic conditions, into the flasks which contained the liquid medium, and the herbicide. Furthermore, the inoculated flasks were incubated at $25^{\circ} \mathrm{C}$. After seven days, the fungal mycelium was obtained, through the process of the culture filtrate. After being washed twice with distilled water, the mycelium was dried overnight at $60^{\circ} \mathrm{C}$, and weighed. There were four replicates of each treatment, and the test was repeated three times. To prepare spore suspension and disperse conidia evenly under aseptic conditions, $5 \mathrm{ml}$ of autoclaved distilled water was added to each slant of one-week-old culture, and mixed vigorously together. The spore suspensions were passed through cheesecloth, counted, and calibrated to $2 \times 10^{5}$ conidia/ml of autoclaved distilled water, with the aid of a hemocytometer.

Statistical analysis. The experiments were conducted, using complete randomized design (CRD) with four replicates. Data from laboratory experiments were analyzed through the use of two-way ANOVA. Mean separation was carried out by Duncan's Multiple Range Test (DMRT), and results were expressed with significant difference at $\mathrm{p}=0.05$.

\section{RESULTS AND DISCUSSION}

Analysis of soil samples. Soil chemical with physical properties were determined and showed in Table 1. The results showed that organic matter $1.85 \%$, EC $2.3 \mu \mathrm{sem} . / \mathrm{cm}$, CIEC $34 \mathrm{~m}$ eq./100 gm, and the soil, were classified as silt clay (54\% silt, $40 \%$ clay, and $6 \%$ sand). The $\mathrm{pH}$ value of sampled soil was determined, as $5.1 \pm 0.02$ and the moisture $34.18 \%$.

Isolated fungi. As shown in Table 2, eight species of fungi were isolated from wheat agricultural fields, belonging to three fungal groups (Ascomyctes, Deutromyctes, Zygomycetes), and six genera (Aspergillus, Penicillium, Curvularia, Rhizopus, Stachybotrys, and Trichoderma). Seven fungi were identified to the species level (A. candidus ATCC 1002, A. niger ATCC 16888, C. lunata B1933, R. stolonifer B9770, S. atra Corda 1837, T. harzianum IOC 3844, and T. lignorum Hartz 1872), except the genus Penicillium sp. Furthermore, results showed that these fungi prefer to be observed in the field soil, for their capacity in degradation of pesticides in soil (Harding \& Raizada, 2015). Being the first record of this toxigenic fungus in Iraq, S. atra, 
was once isolated from the soil of wheat fields in the country.

Table 2. The relative occurrence of the fungal groups and the number of genera isolated from the soil before herbicide application.

\begin{tabular}{llll}
\hline Fungal groups & $\begin{array}{l}\text { No. of } \\
\text { genera }\end{array}$ & $\begin{array}{l}\text { No. of } \\
\text { species }\end{array}$ & $\begin{array}{l}\text { Occurrence } \\
(\%)\end{array}$ \\
\hline Ascomycetes & 5 & 7 & 41.8 \\
Aspergillus & & & \\
candidus & & & \\
A. niger & & \\
Penicillium sp. & & \\
Deutromycetes & & & \\
Cochliobolus & & \\
lunatus & & \\
Stachybotrys & & & \\
chartarum & & & \\
Trichoderma & & & \\
harzianum & & & \\
T. viride & & & \\
Zygomycetes & 1 & 1 & \\
Rhizopus & & & \\
stolonifer & & & \\
\hline
\end{tabular}

Herbicide residues in the soil. The results of 2.4-D degradation in wheat field soil is shown in Table 3. The herbicide 2.4-D, was quickly degraded without lag in period, under certain conditions, specifically soil moisture
(34.18\%), and presence of microorganisms. A length of six weeks or less, was needed for it to be completely degraded, with about $37.5 \%$ broken down after one week, $71.3 \%$ after three weeks, and then totally vanished after five weeks from application. These results confirmed that of (Rhodes, 2014; Spina et al., 2018) that discussed about soil fungi being able to degrade wide range of organic molecules, due to their release of extra-cellular ligninmodifying enzymes.

Table 3. The concentration of the 2.4-D residues in the soil from different periods.

\begin{tabular}{ll}
\hline Period (weeks) & $2.4-\mathrm{D}$ residue conc. $(\%)$ \\
\hline 0 (control) & 0.082 \\
1 & 0.053 \\
2 & 0.034 \\
3 & 0.015 \\
4 & 0.009 \\
5 & 0.000 \\
\hline
\end{tabular}

Fungal population and herbicide residues/field experiments. Effect of 2.4-D on total counts of fungi per gram of fresh soil (for soil depth of $0-15 \mathrm{~cm}$ ) is given in Table 4 .

Table 4. Effect of herbicide treatments on the fungal populations at six exposure periods in soil (cfu/g soil).

\begin{tabular}{|c|c|c|c|c|c|c|c|}
\hline \multirow{3}{*}{ Treatments } & \multicolumn{7}{|c|}{ Weeks after treatment } \\
\hline & \multicolumn{7}{|c|}{ Treatments Fungal population - Colony forming units $\left(\times 10^{4} / \mathrm{g}\right.$ soil $)$} \\
\hline & 0 (cont.) & 1 & 2 & 3 & 4 & 5 & 6 \\
\hline Control & $8.3 \mathrm{c}$ & $8.2 \mathrm{c}$ & $8.3 \mathrm{c}$ & $8.2 \mathrm{c}$ & $8.1 \mathrm{c}$ & $8.2 \mathrm{c}$ & $8.3 \mathrm{c}$ \\
\hline 2.4-D & $8.3 \mathrm{c}$ & $11.5 \mathrm{~b}$ & $12.8 \mathrm{ab}$ & $14.6 \mathrm{a}$ & $11.1 \mathrm{~b}$ & $8.8 \mathrm{c}$ & $8.6 \mathrm{c}$ \\
\hline
\end{tabular}

Notes: Different letters in the same row are significantly different at $\mathrm{p}=0.05$ according to Duncan's test.

Fungal colony development in soil was affected significantly by, the application of the herbicides. Stimulation of fungal colony development among the six exposure periods $(1,2,3,4,5$, and 6 WAT), were significantly higher between two and three WAT, followed by a sharp decline onward. According to the results presented in the table, it was observed that the total counts of fungi increased after 2.4$\mathrm{D}$ treatments, which is the highest in the period, from the $2^{\text {nd }}$ to the $3^{\text {rd }}$ week after the application of herbicides (11.8 and $14.6 \times 10^{4} / \mathrm{g}$ soil, respectively), as compared to control $\left(9.3 \times 10^{4} / \mathrm{g}\right.$ soil $)$. During the $4^{\text {th }}$ and $5^{\text {th }}$ week, their count starts to decrease $\left(9.1\right.$ and $7.8 \times 10^{4}$ / g soil, respectively). The lowest value in the counts of fungi $\left(7.5 \times 10^{4} / \mathrm{g}\right.$ soil $)$, appeared in variance with $2.4-\mathrm{D}$ in the $6^{\text {th }}$ week, after the application of herbicides. The inhibition percentage of the fungal colony development, at the recommended field application rate was non-significant among periods of treatments, from 5 WAT onward. A significant effect on growth of fungal population, was observed among the various 2.4-D herbicide treatments, investigated in the soil environment. These results in correspondence to that of Bernat et al. (2018) that observed 2.4-D presence at high levels, led to a decrease in fungal catalase activity, and their growth. However, the relative occurrence of the fungal species, isolated from the soil treated with 2.4-D was shown in Table 
5. Fungal species showed different degree of sensitivity to herbicide. Among the eight species, growth of three belonged to the genera
Aspergillus sp. and Penicillium sp., while also being mostly affected by the herbicide.

Table 5. The relative occurrence of the fungal species isolated from the field soil treated with 2.4-D.

\begin{tabular}{|c|c|c|c|c|c|c|c|}
\hline \multirow[t]{2}{*}{ Fungal species } & \multicolumn{7}{|c|}{$\begin{array}{l}\text { Weeks after treatment } \\
\text { Relative occurrence }(\%)\end{array}$} \\
\hline & 0 (cont.) & 1 & 2 & 3 & 4 & 5 & 6 \\
\hline A. candidus & $18.12 \mathrm{ab}$ & $16.10 \mathrm{ab}$ & $12.3 \mathrm{c}$ & $11.15 \mathrm{c}$ & $10.30 \mathrm{~cd}$ & $10.12 \mathrm{~cd}$ & $16.14 \mathrm{ab}$ \\
\hline A. niger & $12.30 \mathrm{~b}$ & $10.32 \mathrm{ab}$ & $11.01 \mathrm{~b}$ & $11.60 \mathrm{~b}$ & $12.21 b$ & $13.48 b$ & $13.00 \mathrm{~b}$ \\
\hline Penicillium sp. & $8.05 \mathrm{c}$ & $12.45 \mathrm{ab}$ & $14.33 \mathrm{ab}$ & $17.04 \mathrm{ab}$ & $18.40 \mathrm{ab}$ & $20.44 b$ & $22.40 \mathrm{~b}$ \\
\hline C. lunatus & $3.20 \mathrm{c}$ & $10.30 \mathrm{ab}$ & $11.26 \mathrm{a}$ & $12.03 \mathrm{a}$ & $12.53 \mathrm{a}$ & $12.90 \mathrm{a}$ & $10.45 \mathrm{ab}$ \\
\hline S. atra & $3.61 \mathrm{c}$ & $2.11 \mathrm{a}$ & $1.40 \mathrm{~b}$ & $0.51 \mathrm{c}$ & $0.10 \mathrm{~cd}$ & $0.00 \mathrm{~d}$ & $0.00 \mathrm{~d}$ \\
\hline T. harzianum & $4.10 \mathrm{c}$ & $8.10 \mathrm{~b}$ & $9.88 \mathrm{ab}$ & $10.71 \mathrm{a}$ & $11.32 \mathrm{a}$ & $11.36 \mathrm{a}$ & $8.90 b$ \\
\hline T. lignorum & $11.42 \mathrm{~b}$ & $13.42 \mathrm{ab}$ & $16.71 \mathrm{a}$ & $20.14 \mathrm{a}$ & $22.14 \mathrm{a}$ & $22.00 \mathrm{a}$ & $15.11 \mathrm{ab}$ \\
\hline R. stolonifer & $15.20 \mathrm{~b}$ & $19.40 \mathrm{ab}$ & $19.69 a$ & $21.02 \mathrm{a}$ & $20.90 \mathrm{a}$ & $19.70 \mathrm{a}$ & $18.00 \mathrm{ab}$ \\
\hline
\end{tabular}

One fungal species, S. atra (chartarum), vanished from the soil after the $5^{\text {th }}$ WAT oxidative stress, caused by 2.4-D. Furthermore, the 2.4-D herbicide exhibited a hormonal effect on the species of Trichoderma spp. and $R$. stolonifer, with increased significance in growth rate percentage of these fungi, from $1^{\text {st }}$ to $5^{\text {th }}$ WAT. These results confirmed that of Serbent et al. (2019), that discussed how soil fungi were able to degrade the 2.4-D herbicide, and make use it for their growth. However, the results of this study showed that 2.4-D caused a harmful effect to biodiversity in the soil, by eliminating the fungus $S$. atra, from the field soil. The present results are in accordance with that of Ju et al. (2019), that observed how 2.4D showed antagonistic interactions, against some microorganisms. Furthermore,

Table 6. Effect of 2.4-D on radial growth of fungal species in solid media amended with four rates herbicide in lab experiments.

\begin{tabular}{lllll}
\hline & \multicolumn{4}{l}{ Concentrations of the $2.4-\mathrm{D}(\mu \mathrm{g} / \mathrm{ml})$} \\
\cline { 2 - 5 } Fungal species & $\begin{array}{l}\text { Radial } \\
(\mathrm{cm})\end{array}$ & growth of fungal & species \\
& $\begin{array}{l}0.0 \\
\text { (cont.) }\end{array}$ & 200 & 400 & 800 \\
\hline A. candidus & $8.8 \mathrm{a}$ & $6.0 \mathrm{~b}$ & $5.1 \mathrm{bc}$ & $3.5 \mathrm{~cd}$ \\
A. niger & $8.2 \mathrm{a}$ & $7.3 \mathrm{ab}$ & $6.9 \mathrm{ab}$ & $5.6 \mathrm{c}$ \\
Penicillium $\mathrm{sp}$. & $7.4 \mathrm{a}$ & $8.6 \mathrm{~b}$ & $8.1 \mathrm{~b}$ & $4.9 \mathrm{c}$ \\
C. lunatus & $7.6 \mathrm{ab}$ & $8.1 \mathrm{a}$ & $8.6 \mathrm{a}$ & $5.4 \mathrm{c}$ \\
S. atra & $8.2 \mathrm{a}$ & $3.9 \mathrm{c}$ & $1.6 \mathrm{~d}$ & $0.0 \mathrm{e}$ \\
T. harzianum & $7.1 \mathrm{~b}$ & $8.6 \mathrm{a}$ & $8.1 \mathrm{a}$ & $5.3 \mathrm{c}$ \\
T. lignorum & $7.3 \mathrm{~b}$ & $8.8 \mathrm{a}$ & $8.7 \mathrm{a}$ & $6.0 \mathrm{bc}$ \\
R. stolonifer & $8.0 \mathrm{a}$ & $8.4 \mathrm{a}$ & $8.8 \mathrm{a}$ & $6.1 \mathrm{bc}$ \\
\hline
\end{tabular}

Notes: Different letters in the same row are significantly different at $\mathrm{p}$ $=0.05$ according to Duncan's test. indigenous soil microorganisms possess potentials in biodegradation of 2.4-D, improve soil fertility, and cause significant increase in growth of fungal population (Kumar \& Sai Gopal, 2015). Also, Botero et al. (2017), showed that soil microorganisms used part of 2.4-D, to produce biomass, and are involved in the formation of bound residues. Also, it was observed that fungi are excellent bioagents for hydrocarbon remediation (Treu \& Falandysz, 2017).

Fungal population and herbicide residues/lab experiments. The results of herbicide effects on fungal growth in lab experiments, were given in Table 6 , for growth in solid media (colony radial growth), and in Table 7, for growth in liquid media (dry weight of mycelium mat).

Table 7. Effect of 2.4-D on dry weight mycelia growth of fungal species in liquid media amended with four rates of herbicide.

\begin{tabular}{lllll}
\hline & \multicolumn{5}{l}{ Concentrations of the $2.4-\mathrm{D}(\mu \mathrm{g} / \mathrm{ml})$} \\
& \multicolumn{4}{l}{ Dry weight of mycelium growth $(\mathrm{g})$} \\
& 0.0 & 200 & 400 & 800 \\
& (cont.) & & & \\
\hline A. candidus & $1.68 \mathrm{a}$ & $1.23 \mathrm{~b}$ & $0.95 \mathrm{c}$ & $0.72 \mathrm{~d}$ \\
A. niger & $1.50 \mathrm{a}$ & $1.48 \mathrm{ab}$ & $1.36 \mathrm{ab}$ & $0.93 \mathrm{c}$ \\
Penicillium & $1.35 \mathrm{a}$ & $1.54 \mathrm{~b}$ & $1.61 \mathrm{~b}$ & $0.84 \mathrm{c}$ \\
sp. & & & & \\
C. lunatus & $1.19 \mathrm{a}$ & $1.42 \mathrm{~b}$ & $1.57 \mathrm{a}$ & $0.51 \mathrm{c}$ \\
S. atra & $1.30 \mathrm{a}$ & $0.65 \mathrm{bc}$ & $0.22 \mathrm{c}$ & $0.00 \mathrm{~d}$ \\
T. harzianum & $1.16 \mathrm{a}$ & $1.40 \mathrm{~b}$ & $1.55 \mathrm{~b}$ & $0.71 \mathrm{c}$ \\
T. lignorum & $1.42 \mathrm{a}$ & $1.79 \mathrm{~b}$ & $1.72 \mathrm{~b}$ & $0.80 \mathrm{c}$ \\
R. stolonifer & $1.41 \mathrm{a}$ & $1.68 \mathrm{~b}$ & $1.81 \mathrm{bc}$ & $0.85 \mathrm{~d}$ \\
\hline
\end{tabular}

Notes: Different letters in the same row are significantly different at $\mathrm{p}$ $=0.05$ according to Duncan's test. 
Generally, the treatments of 2.4-D to the solid or liquid media, exhibited similar results at all concentrations. Fungal species showed different degree of sensitivity to different herbicide rates. The herbicide treatments, restricted the growth of four fungal species belonging to three genera (Aspergillus spp., Penicillium sp., and Stachybotrys sp.), by isolating them from the soil of wheat plantation. The lowest herbicide concentration $200 \mu \mathrm{g} / \mathrm{ml}$ $(0.5 \times$ recommended field application rate), caused growth inhibition of these four species in both solid and liquid media, between $20 \%$ $30 \%$, as compared to the control. Growth inhibition became more severe with increasing concentration of the herbicides, even in reduction of the extended vegetative hyphae on solid media, or in that of mycelial mats in the liquid media. Among the eight species, the growth of $S$. atra, was mostly affected by all the herbicide rates, and the highest concentration $800 \mu \mathrm{g} / \mathrm{ml}(2 \times$ recommended field application rate), caused $100 \%$ inhibition to growth development of this fungus. In contrast, the 2.4D treatments at low concentrations of $200 \mu \mathrm{g} / \mathrm{ml}$ and $400 \mu \mathrm{g} / \mathrm{ml}(0.5$ and $1 \times$ recommended field application rate, respectively), exhibited hormonal effects on three fungal species, belonging to two genera (Trichoderma spp. and Rhizopus sp.). However, the high concentration $800 \mu \mathrm{g} / \mathrm{ml}(2 \times$ recommended field application rate), had a slight toxic effect on growth of all species in both solid and liquid media, while exhibiting an inhibition to the radial growth, and the mycelial mats between 5\%-100\%, with respect to the control, after seven days of incubation. Among the eight species, the growth of $S$. atra was mostly affected by all the rates of herbicide, and disappeared at the highest concentration. Results of this study, indicated that fungal population showed different degree of sensitivity to $2.4-\mathrm{D}$, at different exposure periods and concentrations, with this observation probably due to the differing abilities of fungal mycelia, to absorb herbicides for their utilization. These observed results were similar to that of Zain et al. (2013) that discussed how fungal inhibition varied among fungal species, and the herbicide treatments.

\section{CONCLUSION}

This study discusses the fungus $S$. atra, for the first time in the Iraqi field soil, and how it vanished after herbicide application. This fungus known as black toxic mold, biologically produces potent mycotoxins. Also, the results emphasized that soil fungi potentially play a major role in the degradation of 2.4-D herbicide, and lead to formation of hydroxylated metabolites in soils treated with the herbicide to help enhance growth. However, a significant negative effect was observed only on the toxigenic fungus $S$. atra, which was eliminated from the soil. The inhibition or stimulation effect of herbicide on fungal growth, depended on the fungus, and the soil type. Also, it was observed that, 2.4-D affected the microbial biodiversity of the field. Furthermore, results showed that the herbicide had substantial effects on microbial population, and specifically, soil fungi were responsible for the mineralization of 2.4-D. The higher concentrations of herbicides treatments resulted in much lower fungal counts, when compared to soils treated with recommended doses. Therefore, this consequently explains the increase in microbial population, as obtained in this study, from the second to the fifth week of herbicide application.

\section{REFERENCES}

Adomako MO, Akyeampong S. 2016. Effect of some commonly used herbicides on soil microbial population. Journal of Environment and Earth Science. vol 6(1): 30-38.

Banks ML, Kennedy AC, Kremer RJ, Eivazi F. 2014. Soil microbial community response to surfactants and herbicides in two soils. Applied Soil Ecology. vol 74: 12-20. doi: https://doi.org/10.1016/j.apsoil.2013.08.018.

Bernat P, Nykiel-Szymańska J, Stolarek P, Słaba M, Szewczyk R, Różalska S. 2018. 2.4dichlorophenoxyacetic acid-induced oxidative stress: Metabolome and membrane modifications in Umbelopsis isabellina, a herbicide degrader. Plos One. vol 13(6): 1-18. doi: doi.org/10.1371/journal.pone.0199677.

Botero LR, Mougin C, Peñuela G, Barriuso E. 2017. Formation of 2,4-D bound residues in soils: New insights into microbial metabolism. Science of the Total Environment. vol 584: 715-722. doi: https://doi.org/10.1016/j.scitotenv.2017.01.105.

Ceballos R, Quiroz A, Palma G. 2011. Effects of postemergence herbicides on in vitro growth of 
Fusarium oxysporum isolated from clover root rot. Journal of Soil Science and Plant Nutrition. vol. 11 (2): 1-7. doi: https://doi.org/10.4067/S0718 95162011000200001

Diez MC. 2010. Biological aspects involved in the degradation of organic pollutants. Journal of Soil Science and Plant Nutrition. vol 10(3): 244-267. doi: $\quad$ https://doi.org/ 10.4067/S0718 95162010000100004.

Escamilla D, Rosso ML, Zhang B. 2019. Identification of fungi associated with soybeans and effective seed disinfection treatments. Food Science and Nutrition. vol 7(10): 3194-3205. doi: https://doi.org/10.1002/fsn3.1166.

Fernando WD, Li R. 2012. Opening the black box: understanding the influence of cropping systems and plant communities on bacterial and fungal population dynamics. Ceylon Journal of Science (Biological Sciences). vol 41(2): 89-110. doi: http://dx.doi.org/10.4038/cjsbs.v41i2.5380.

Fang G, Si Y, Tian C, Zhang G, Zhou D. 2012. Degradation of 2, 4-D in soils by $\mathrm{Fe}_{3} \mathrm{O}_{4}$ nanoparticles combined with stimulating indigenous microbes. Environmental Science and Pollution Research. vol 19(3): 784-793. doi: https://doi.org/10.1007/s11356-011-0597-y.

Ferreira-Guedes S, Mendes B, Leitão AL. 2012. Degradation of 2, 4-dichlorophenoxyacetic acid by a halotolerant strain of Penicillium chrysogenum: antibiotic production. Environmental Technology. vol 33(6): 677-686. doi: https://doi.org/10.1080/09593330.2011.588251.

Goswami M, Chakraborty P, Mukherjee K, Mitra G, Bhattacharyya P, Dey S, Tribedi P. 2018. Bioaugmentation and biostimulation: a potential strategy for environmental remediation. Journal of Microbiology and Experimentation. vol 6(5): 223231. https://doi.org/10.15406/jmen.2018.06.00219.

Harding DP, Raizada MN. 2015. Controlling weeds with fungi, bacteria and viruses: a review. Frontiers in Plant Science. vol 6: 1-14. doi: https://doi.org/10.3389/fpls.2015.00659.

Ju Z, Liu SS, Xu YQ, Li K. 2019. Combined toxicity of 2, 4-dichlorophenoxyacetic acid and its metabolites 2, 4-dichlorophenol (2, 4-DCP) on two nontarget organisms. ACS Omega. vol 4(1): 1669-1677. doi: https://doi.org/10.1021/acsomega.8b02282.

Kumar A, Trefault N, Olaniran AO. 2016. Microbial degradation of 2, 4-dichlorophenoxyacetic acid: insight into the enzymes and catabolic genes involved, their regulation and biotechnological implications. Critical Reviews in Microbiology. vol 42(2): 194-208. doi: https://doi.org/10.3109/1040841X.2014.917068.

Kumar BL, Sai Gopal DVR. 2015. Effective role of indigenous microorganisms for sustainable environment. 3 Biotech. vol 5(6): 867-876. doi: https://doi.org/10.1007/s13205-015-0293-6.
Nikolaivits E, Agrafiotis A, Termentzi A, Machera K, Le Goff $\mathrm{G}$, Álvarez $\mathrm{P}$, Chavanich S,Benayahu Y, Ouazzani J, Fokialakis N, Topakas E. 2019. Unraveling the detoxification mechanism of 2, 4dichlorophenol by marine-derived mesophotic symbiotic fungi isolated from marine invertebrates. Marine Drugs. vol 17(10): 1-11. doi: https://doi.org/10.3390/md17100564.

Nykiel-Szymańska J, Stolarek P, Bernat P. 2018. Elimination and detoxification of 2, 4-D by Umbelopsis isabellina with the involvement of cytochrome P450. Environmental Science and Pollution Research. vol 25(3): 2738-2743. doi: https://doi.org/10.1007/s11356-017-0571-4.

Rhodes CJ. 2014. Mycoremediation (bioremediation with fungi)-growing mushrooms to clean the earth. Chemical Speciation \& Bioavailability. vol 26(3): 196-1198.

doi: https://doi.org/.10.3184/095422914X14047407349 335.

Ross DJ. 1992. Influence of sieve mesh size on estimates of microbial carbon and nitrogen by fumigationextraction procedures in soils under pasture. Soil Biology and Biochemistry. vol 24(4): 343-350. doi: https://doi.org/10.1016/0038-0717(92)90194-3.

Serbent MP, Rebelo AM, Pinheiro A, Giongo A, Tavares LBB. 2019. Biological agents for 2, 4dichlorophenoxyacetic acid herbicide degradation. Applied Microbiology and Biotechnology. vol 103(13): 5065-5078. doi: https://doi.org/10.1007/s00253-019-09838-4.

Spina F, Cecchi G, Landinez TA, Pecoraro L, Russo F, Wu B. 2018. Fungi as a toolbox for sustainable bioremediation of pesticides in soil and water. Plant Biosystems. vol 152 (3): 474-488. doi: https://doi.org/10.1080/11263504.2018.1445130.

Tétard-Jones C, Edwards R. 2016. Potential roles for microbial endophytes in herbicide tolerance in plants. Pest Management Science. vol 72(2): 203209. doi: https://doi.org/10.1002/ps.4147.

Treu R, Falandysz J. 2017. Mycoremediation of hydrocarbons with basidiomycetes-a review. Journal of Environmental Science and Health, Part B. vol 52(3): 148-155. doi: https://doi.org/10.1080/03601234.2017.1261536.

Urík M, Boriová K, Bujdoš M, Matúš P. 2016. Fungal selenium (VI) accumulation and biotransformation-filamentous fungi in selenate contaminated aqueous media remediation. CLEANSoil, Air, Water. vol 44(6): 610-614. doi: https://doi.org/10.1002/clen.201500100.

van de Voorde TF, van der Putten WH, Bezemer TM. 2012. Soil inoculation method determines the strength of plant-soil interactions. Soil Biology and Biochemistry. vol 55: 1-6. doi: https://doi.org/10.1016/j.soilbio.2012.05.020.

Xia ZY, Zhang L, Zhao Y, Yan X, Li SP, Gu T, Jiang JD. 2017. Biodegradation of the herbicide 2.4dichlorophenoxyacetic acid by a new isolated strain of Achromobacter sp. 
Microbiology. vol 74(2): 193-202. doi: https://doi.org/10.1007/s00284-016-1173-y.

Zain NMM, Mohamad RB, Sijam K, Morshed MM, Awang Y. 2013. Effects of selected herbicides on soil microbial populations in oil palm plantation of Malaysia: A microcosm experiment. African
Journal of Microbiology Research. vol 7(5): 367374. doi: https://doi.org/10.5897/AJMR12.1277.

Zhang C, Liu X, Dong F, Xu J, Zheng Y, Li J. 2010. Soil microbial communities response to herbicide 2, 4dichlorophenoxyacetic acid butyl ester. European Journal of Soil Biology. vol 46(2): 175-180. doi: https://doi.org/10.1016/j.ejsobi.2009.12.005. 